BREED CHOICE FOR HILL AND UPLAND SHEEP FARMS 


\title{
THE CHOICE OF SHEEP BREEDS ON HILL AND UPLAND FARMS
}

\author{
G. E. POLLOTT
}

\author{
Meat and Livestock Commission, PO Box 44, Bletchley, Milton Keynes MK2 2EF
}

\begin{abstract}
Ithough not a random sample of flocks, results from A MLC's Flockplan scheme do give an indication of the breeds used in hill and upland flocks. Table 1 shows the proportions of recorded stock falling into the major breeds for both ewes and rams in hill flocks.
\end{abstract}

TABLE 1

Percenlage of ewes and rams by breed from hill flocks

\begin{tabular}{lcc}
\multicolumn{1}{c}{ Breed } & \% of ewes & $\%$ of rams \\
Scottish Blackface & 32 & 26 \\
Swaledale & 18 & 11 \\
Welsh Mountain & 25 & 19 \\
South Welsh Mountain & 6 & 6 \\
North Country Cheviot & 4 & 7 \\
Hardy Speckleface & 4 & 3 \\
Bluefaced Leicester & - & 8 \\
Suffolk & - & 8
\end{tabular}

The choice of ewe breed in the hills is confined to the traditional hill breeds with other types not contributing significantly to the hill ewe population. Choice within the hill types is available and, in certain parts of the country, breed substitution between Swaledales and Blackfaces, Cheviots and Blackfaces and the Welsh breeds is not unknown.

The majority of rams used in hill flocks are also of the traditional hill types and are used to maintain purebred ewe replacements in these flocks. However, as Table 1 shows, there is an attempt to increase income in hill flocks by producing lambs for sale to specialist markets. The Bluefaced Leicester breed constituted $8 \%$ of the rams used and shows how hill farmers are attempting to increase their incomes by selling Mule-type ewe lambs. A further $8 \%$ of rams used were Suffolks, producing finished lambs for sale and some crossbred ewe lambs.
There would seem to be more scope in ram breed choice than ewe breed choice in hill flocks.

Table 2 shows the ewe and ram breeds found in upland areas.

TABLE 2

Percentage of ewes and rams by breed from upland flocks

Scottish Blackface

Swaledale

Welsh Mountain

Beulah Speckledface

Hardy Speckledface

Mule

Greyface

Welsh Halfbred

Welsh Mule

Border Leicester

Bluefaced Leicester

Suffolk

$\%$ ewes $\%$ rams

Texel

$\begin{array}{rr}8 & - \\ 5 & - \\ 13 & 4 \\ 11 & - \\ 6 & - \\ 17 & - \\ 4 & - \\ 5 & - \\ 3 & - \\ - & 8 \\ - & 14 \\ - & 53 \\ - & 8\end{array}$

Forty-three per cent of the ewes on upland farms were of the draft hill ewe type and $29 \%$ were upland crossbreds from the Swaledale. Welsh Mountain and Scottish Blackface breeds.

The rams found on upland farms show a clear choice between finished lamb sires $(61 \%)$ and crossbred ewe lamb sires $(22 \%)$. The Suffolk breed is the predominant sire breed.

Financed results from upland farms demonstrate that flocks producing crossbred ewe lambs for sale achieve higher output, at a lower cost than finished lamb producers. They also stock their ewes more heavily and thus achieve a gross margin of $\mathbf{f} 646$ per ha compared to $\mathbf{E} \mathbf{6 0}$ for finished lamb flocks. 